\title{
PENGARUH BAHAN ASAL STEK DAN MEDIA TANAM TERHADAP PERTUMBUHAN NILAM (Pogostemon cablin Benth)
}

\author{
Oleh: \\ River Wedilen Bona Simatupang*, Irwan Mahakam Lesmono Aji, dan Dwi Sukma Rini \\ Program Studi Kehutanan Universitas Mataram \\ riverwedilensimatupang@gmail.com
}

\begin{abstract}
Abtract
Patchouli plant (Pogostemon cablin Benth.) is one of the essential oil producing plants that is useful in the fields of pharmaceutical, cosmetics and perfume as a mixture or fixation (binding of fragrances). The success rate of patchouli early growth, is largely determined by the cultivation techniques used, one of which includes vegetative cultivation of various selected stem cutting, and planting media. This study aims to determine the effect of material from cuttings and planting media on the growth of patchouli plants. The research was conducted at the Greenhouse of the University of Mataram Forestry Study Program, using a Factorial Completely Randomized Design (FCRD). The first factor is various stem cutting with three levels, namely tip stem cuttings, middle stem cuttings and base stem cuttings and the second factor is planting media with four levels, namely forest soil media, soil:cocopeat (1:1), soil:cocopeat (1:2) and soil:cocopeat (2:1). The results showed that the effect of material from stem significantly affected the percentage of life, number of shoots, number of leaves, shoot length. For the planting media, it had a significant effect on the length of the shoot, shoot diameter, leaf area, dry trimming weight. The interaction effect of various stem cutting and plan media did not have a significant effect on the growth parameters of patchouli. The treatment of material from cuttings in patchouli plants had the best growth effect on the treatment of $S 2$ (middle stem cuttings) and the treatment of planting media had the best growth effect on the MO (soil media) treatment.
\end{abstract}

Keywords : Dampak, Perladangan Liar, Masyarakat

Abstrak

Tanaman nilam (Pogostemon cablin Benth.) merupakan salah satu tanaman penghasil minyak atsiri (esential oils) yang bermanfaat dalam bidang, farmasi, kosmetik dan parfum sebagai bahan campuran atau fiksasi (pengikat wangi-wangian). Tingkat keberhasilan dari pertumbuhan awal nilam, sangat ditentukan oleh teknik budidaya yang digunakan, salah satunya termasuk pembudidayaan vegetatif dari berbagai bibit stek yang dipilih, dan media tanam. Penelitian ini bertujuan untuk mengetahui pengaruh bahan asal stek dan media tanam terhadap pertumbuhan tanaman nilam. Penelitian dilaksanakan di Greenhouse Program Studi Kehutanan Universitas Mataram, dengan menggunakan Rancangan Acak Lengkap Faktorial (RALF). Faktor pertama adalah bahan asal stek dengan 3 aras yaitu stek pucuk, stek batang tengah dan stek batang pangkal dan faktor kedua adalah media tanam dengan 4 aras yaitu media tanah hutan, media tanah:cocopeat (1:1), media tanah:cocopeat (1:2) dan media tanah:cocopeat (2:1). Hasil penelitian menunjukkan bahwa pengaruh bahan asal stek berpengaruh nyata terhadap persentase hidup, jumlah tunas, jumlah daun, panjang tunas. Untuk media tanam berpengaruh nyata terhadap panjang tunas, diameter tunas, luas daun, berat berangkas kering. Adapun interaksi bahan asal stek dan media tanam tidak memberikan pengaruh yang nyata terhadap parameter pertumbuhan tanaman nilam. Perlakuan bahan asal stek pada tanaman nilam memiliki pengaruh pertumbuhan paling baik pada perlakuan S2 (stek batang tengah) dan pada perlakuan media tanam memiliki pengaruh pertumbuhan paling baik pada perlakuan M0 (media tanah).

Kata Kunci: Nilam, Bahan Asal Stek, Media Tanam, Media Cocopeat. 


\section{PENDAHULUAN}

Nilam (Pogostemon cablin Benth.) merupakan herba tropis penghasil minyak atsiri yang dalam perdagangan internasional dikenal sebagai minyak patchouli (patchai: hijau dan ellai: daun) (Rusli,2010). Nilam dikembangkan karena mempunyai alasan sebagai salah satu penyumbang devisa di Negara Indonesia berangkat dari minyak atsiri yang dihasilkan dari produk (Hasil Hutan Bukan Kayu) (Krismawati, 2005). Minyak atsiri (Patchouli oil) adalah produk olahan yang merupakan hasil minyak yang diperoleh melalui tanaman-tanaman tertentu dari 70 jenis minyak atsiri yang diperdagangkan di pasar internasional di Indonesia (Rusli, 2010).

Menurut data yang dilansirkan oleh Direktorat Jenderal Perkebunan pada tahun 2016 tentang minyak atsiri khususnya yang berasal dari nilam, merupakan jenis komuditas ekspor dengan persentase tertinggi, di mana Indonesia memasok sekitar $90 \%$ dari kebutuhan dunia atau 1.600 ton per tahun. Adapun nilai ekspor di komoditas nilam, pada tahun 2015 mencapai mencapai US\$ $=23,933$ milyar atau setara dengan $\mathrm{Rp}$ 311,138 triliun dengan asumsi 1US $\$=$ Rp.13.000 (Direktorat Jenderal Perkebunan, 2017).

Sebagai komoditas ekspor yang baik sehingga dibutuhkan secara kontinyu dan bernilai ekonomi yang cukup tinggi pada minyak atsiri, hal ini disebabkan karena nilam mempunyai banyak manfaat, menurut Mangun et al (2012) bahwa minyak nilam memiliki manfaat yang cukup bervariasi biasanya digunakan sebagai bahan baku pengikat (fiksasi), selain itu minyak nilam dapat digunakan sebagai bahan pengendali penerbang (eteris) untuk parfum, bahan campuran produk kosmetik, industri makanan, industri farmasi, serta berbagai kebutuhan industri lainnya.

Pada tahun 2017 KPH Rinjani Barat mulai mengembangkan tanaman nilam, karena memiliki prospek bisnis yang sangat menjanjikan sehingga atas dorongan tersebut masyarakat sekitar hutan mulai melakukan pembudidaayan yang pada akhirnya masyarakat mendapat manfaat yang optimal dalam pengelolaan hutan. Dilihat pengembangan terhadap tanaman nilam bahwa hal yang paling penting adalah menjaga nilai ekspor, manfaat serta potensinya. Untuk menjaga ketiga poin penting tersebut maka hal mendasar yang harus diketahui adalah cara pembudidayaan yang baik, salah satu caranya adalah memilih bibit bahan stek dan media tanam yang tepat.

Stek yang baik merupakan stek yang mampu menghasilkan akar dan tunas yang seimbang Rismunandar (1995), mengemukakan bawah dari pembentukan akar pada stek memerlukan energi yang diperoleh dari tubuhnya sendiri. Energi tersebut diperoleh dari karbohidrat dan protein yang tersimpan dalam jaringan. Bila stek memiliki kandungan karbohidrat dan protein seimbang maka pertumbuhan yang dihasilkan sangat baik dalam pertumbuhan akar dan tunas. Peran akar sebagai penyerap unsur hara dan tunas sebagai penghasil daun yang berperan penting dalam fotosintesis.

Selain faktor dari bahan asal stek media tanam juga mempengaruhi pertumbuhan tanaman. Fungsi media tanam adalah sebagai tempat menancapnya akar tanaman dan tumbuh berkembang. Selain itu juga media memiliki fungsi yang paling utama yaitu sebagai penyedia unsur hara dan air yang dimanfaatkan oleh tanaman. Cocopeat bisa dijadikan contoh sebagai media tanam yang memiliki unsur hara yang tersedia dan memiliki daya serap air yang tinggi.

Bertolak dari uraian tersebut dalam upaya meningkatkan produktivitas nilam, penelitian ini perlu dilakukan yang berjudul, penelitian ini perlu dilakukan yang berjudul "Pengaruh Bahan Asal Stek Dan Pemberian Media Tanam Terhadap Pertumbuhan Nilam (pogostemon cablin benth)".

\section{METODOLOGI PENELITIAN}

Penelitian ini dilaksanakan pada bulan April- Juli 2019 di Green House Program Studi Kehutanan Universitas Mataram. Alat-alat dan bahan yang digunakan adalah pengayak tanah, gembor, polybag, sekop mini, cangkul, kertas label, kamera, penggaris, timbangan analitik, karung, alat tulis, tallysheet, kaliper, stek nilam (Pogostemon cablin) (stek pucuk, stek batang tengah dan stek batang pangkal), serbuk sabut kelapa (cocopeat), tanah dan tanah hutan.

Metode yang digunakan dalam penelitian ini adalah metode eksperimental yang merupakan kegiatan percobaan dan membandingankan suatu faktor yang diujikan guna mengetahui hasil dan mendapatkan informasi dari hasil percobaan tersebut (Hanafiah, 2016). Rancangan Percobaan yang 
digunakan adalah model Rancangan Acak Lengkap Faktorial (RAL Faktorial). Perlakuan terdiri dari 2 faktor. Faktor pertama yaitu bahan asal stek yang terdiri dari 3 aras yaitu S1 (Stek pucuk), S2 (Stek batang tengah), S3 (Stek batang pangkal) dan faktor kedua yaitu media tanam yang terdiri dari 4 aras yaitu M0 (Tanah), M1 (Tanah+cocopeat 1:1), M2 (Tanah + cocopeat 1:2), M3 (Tanah + cocopeat 2:1) .Dari kedua faktor tersebut diperoleh 12 kombinasi perlakuan, masing-masing kombinasi perlakuan diulang 3 kali sehingga total unit percobaan 36 polybag. Parameter yang diukur dalam penelitian ini meliputi persentase hidup, jumlah tunas, jumlah daun, panjang tunas, diameter tunas, luas daun, dan berat berangkas kering. Analisis data menggunakan analisis keragaman (anova) pada taraf 5\% dan uji lanjut dengan uji Duncan (DMRT).

\section{HASIL dan PEMBAHASAN}

\section{a. Analisis Pertumbuhan}

Analisis pertumbuhan merupakan suatu cara mengikuti dinamika fotosintesis yang diukur oleh produksi tanaman atau suatu cara untuk memperoleh ukuran kuantitatif dalam mengikuti dan membandingkan pertumbuhan tanaman, dalam aspek fisiologi maupun ekologis, baik secara individu maupun kelompok (Mursito \& Kawiji, 2002).

Tabel 1. Hasil Analisis Sidik Ragam Parameter Penelitian

\begin{tabular}{|c|c|c|c|c|}
\hline No & Parameter & $\begin{array}{l}\text { Bahan } \\
\text { Asal Stek }\end{array}$ & Media Tanam & $\begin{array}{l}\text { Bahan Asal } \\
\text { Stek dan } \\
\text { Media } \\
\text { Tanam }\end{array}$ \\
\hline 1 & $\begin{array}{l}\text { Persentase } \\
\text { Hidup }\end{array}$ & $*$ & $\mathrm{~ns}$ & ns \\
\hline 2 & Jumlah Tunas & $* *$ & ns & ns \\
\hline 3 & Jumlah Daun & $* *$ & ns & ns \\
\hline 4 & Panjang Tunas & $*$ & $* *$ & ns \\
\hline 5 & $\begin{array}{l}\text { Diameter } \\
\text { Tunas }\end{array}$ & ns & $* *$ & ns \\
\hline 6 & Luas Daun & ns & $* *$ & ns \\
\hline 7 & $\begin{array}{l}\text { Berat } \\
\text { Berangkas } \\
\text { Kering }\end{array}$ & ns & $*$ & ns \\
\hline
\end{tabular}

\section{b. Persentase Hidup}

Persentase stek tumbuh merupakan indikator keberhasilan penyetekan. Secara umum pertumbuhan adalah suatu proses yang dilakukan oleh tanaman hidup pada lingkungan tertentu dan dengan sifat-sifat tertentu untuk menghasilkan kemajuan perkembangan dengan menggunakan faktor lingkungan (Sitompul \& Guritno, 1995). Persentase stek tumbuh merupakan indikator keberhasilan penyetekan.

Tabel 2. Pengaruh Perlakuan bahan asal stek terhadap persentase hidup tanaman nilam

\begin{tabular}{llll}
\hline Perlakuan & Kode & $\begin{array}{l}\text { Nilai Rata- } \\
\text { Rata }(\%)\end{array}$ & Notasi \\
\hline $\begin{array}{l}\text { Pucuk } \\
\text { Batang }\end{array}$ & $\mathrm{S}_{1}$ & 77,9 & $\mathrm{ab}$ \\
$\begin{array}{l}\text { Tengah } \\
\text { Batang }\end{array}$ & $\mathrm{S}_{2}$ & 88,9 & $\mathrm{a}$ \\
Pangkal & $\mathrm{S}_{3}$ & 55,5 & $\mathrm{~b}$ \\
\hline
\end{tabular}

Tingkat persentase hidup pada masingmasing bahan stek, mempunyai nilai yang berbeda satu sama lain. Perbedaan tersebut diduga karena persentase hidup dari bahan asal stek dipengaruhi oleh umur, perbedaan ketersediaan energi atau cadangan makanan yang terkandung di dalamnya, sehingga dapat memacu adanya pertumbuhan organ-organ penting seperti pertumbuhan akar dan tunas. Keadaan ini sesuai dengan yang dikemukakan Hartman et al (1990), bahwa keberhasilan bahan asal stek dalam pembentukan akar dipengaruhi oleh umur tanaman, fase pertumbuhan dan perbedaan bagian tanaman yang digunakan sebagai bahan stek. Bagian pada batang tersebut berkaitan dengan kandungan nutrisi didalamnya terutama karbohidrat, protein, dan nitrogen.

\section{c. Jumlah Tunas}

Tunas pada umumnya merupakan suatu pertumbuhan batang muda yang terjadi pada bagian buku batang suatu tanaman atau ujung batang tanaman induk yang pada mulanya berkembang dan menjadi bagian batang utama sehingga menghasilkan daun muda yang digunakan untuk fotosintesis (Sitompul \& Guritno, 1995).

Tabel 3. Pengaruh Perlakuan bahan asal stek terhadap jumlah tunas tanaman nilam

\begin{tabular}{llll}
\hline Perlakuan & Kode & $\begin{array}{l}\text { Nilai Rata- } \\
\text { Rata (tunas) }\end{array}$ & Notasi \\
\hline $\begin{array}{l}\text { Pucuk } \\
\text { Batang }\end{array}$ & $\mathrm{S}_{1}$ & 1,3 & $\mathrm{~b}$ \\
$\begin{array}{l}\text { Tengah } \\
\text { Batang }\end{array}$ & $\mathrm{S}_{2}$ & 3,0 & $\mathrm{a}$ \\
Pangkal & $\mathrm{S}_{3}$ & 2,8 & \\
\hline
\end{tabular}

Keterangan: Notasi huruf yang sama pada Tabel menunjukkan tidak beda nyata, notasi huruf yang berbeda menunjukkan beda nyata. 
Hasil dari penelitian ini menunjukkan bahwa pertumbuhan jumlah tunas stek pucuk bervariasi. Diduga dari bahan stek pucuk $\left(\mathrm{S}_{1}\right)$ memiliki umur yang lebih juvenil daripada stek batang tengah $\left(\mathrm{S}_{2}\right)$ dan stek pangkal $\left(\mathrm{S}_{3}\right)$ yang memiliki umur lebih tua, sehingga batang yang lebih tua memiliki ketersediaan karbohidrat, nitrogen yang seimbang untuk mendukung pertumbuhan jumlah tunas yang terdapat pada batang stek, namun pada stek pucuk $\left(\mathrm{S}_{1}\right)$ cenderung memiliki auksin lebih tinggi dibandingkan dengan dibawahnya yaitu stek batang tengah $\left(\mathrm{S}_{2}\right)$ dan stek batang pangkal $\left(\mathrm{S}_{3}\right)$, karena auksin suatu tanaman diproduksi dari jaringan meristem dan menyebabkan adanya dominasi apikal. Syakir et al (1992) mengatakan kandungan auksin yang terdapat pada perbanyakan stek lebih dominan terhadap stek yang lebih muda sehingga pertumbuhan tunas yang dihasilkan cenderung pada pertumbuhan tunas apikal (tunas pucuk). Terjadinya dominasi apikal pada stek pucuk membuat sering terjadinya dorman dibagian pembentukkan tunas lateral.

\section{d. Jumlah Daun}

Daun pada umumnya merupakan salah satu bagian yang terdapat dari bagian tanaman, biasa tumbuh di bagian sela-sela batang atau pada bagian pucuk tanaman induk itu sendiri, mempunyai ciri-ciri berwana hijau dan mengandung klorofil. Fungsi dari daun sangat penting untuk tanaman salah satunya yang terpenting adalah sebagai penangkap energi dari cahaya matahari untuk berfotosintesis (Sitompul \& Guritno (1995).

Tabel 4. Pengaruh Perlakuan bahan asal stek terhadap jumlah daun tanaman nilam

\begin{tabular}{lllll}
\hline Perlakuan & \multicolumn{3}{c}{ Kilai Rata- } \\
Kucuk & $\mathrm{S}_{1}$ & 11,1 & Notasi \\
\hline Batang Tengah & $\mathrm{S}_{2}$ & 22,3 & $\mathrm{~b}$ \\
Batang Pangkal & $\mathrm{S}_{3}$ & 22,2 & $\mathrm{a}$ & \multicolumn{2}{c}{$\mathrm{a}$} \\
\hline Keterangan:Notasi huruf & yang & sama pada & Tabel \\
menunjukkan tidak beda nyata, notasi huruf & yang \\
berbeda menunjukkan beda nyata & &
\end{tabular}

Dari tingkat pertumbuhan pada jumlah daun menunjukkan bahwa batang tengah $\left(S_{2}\right)$ menghasilkan jumlah daun terbanyak. Diduga pertumbuhan pada stek batang tengah $\left(\mathrm{S}_{2}\right)$ dan stek batang pangkal $\left(\mathrm{S}_{3}\right)$ lebih didominasi banyak tunas dan panjang tunas lebih tinggi, karena dipengaruhi adanya persediaan energi karbohidrat dan nitrogen seimbang, sedangkan stek pucuk $\left(\mathrm{S}_{1}\right)$ lebih lambat pertumbuhan tunasnya karena terjadinya dominasi apikal yang dipengaruhi tingkat auksin lebih banyak, secara otomatis banyak nya daun pada stek batang tengah $\left(\mathrm{S}_{2}\right)$ dan stek batang pangkal $\left(\mathrm{S}_{3}\right)$ dipengaruhi oleh banyaknya jumlah tunas dan pertumbuhan panjang tunas. Karnedi (1998 cit Yustisia, 2016) mengatakan semakin banyak tunas yang dihasilkan, semakin banyak pula jumlah daun yang dihasilkan.

\section{e. Panjang Tunas}

Pertumbuhan dapat dicirikan dengan kenaikan panjang suatu tanaman atau kenaikan panjang dari bagian tanaman, sedangkan peningkatan jumlah sel dan ukuran sel terjadi pada jaringan meristem ujung, meristem interkalar dan meristem lateral. Pertumbuhan pada meristem ujung menghasilkan sel-sel baru diujung sehingga mengakibatkan tanaman bertambah tinggi dan panjang (Sumiati, 1999).

Tabel 5. Pengaruh Perlakuan bahan asal stek terhadap panjang tunas tanaman nilam

\begin{tabular}{llll}
\hline Perlakuan & Kode & $\begin{array}{l}\text { Nilai Rata- } \\
\text { Rata }(\mathbf{c m})\end{array}$ & Notasi \\
\hline Pucuk & $\mathrm{S}_{1}$ & 5,4 & $\mathrm{a}$ \\
Batang Tengah & $\mathrm{S}_{2}$ & 9,7 & $\mathrm{a}$ \\
Batang Pangkal & $\mathrm{S}_{3}$ & 9,1 & $\mathrm{a}$ \\
\hline
\end{tabular}

Keterangan: Notasi huruf yang sama pada Tabel menunjukkan tidak beda nyata, notasi huruf yang berbeda menunjukkan beda nyata.

\section{f. Diameter Tunas}

Dari tingkat pertumbuhan panjang tunas menunjukkan bahwa batang tengah $\left(\mathbf{S}_{2}\right)$ menghasilkan tunas terpanjang. Diduga pengaruh pertumbuhan tinggi tunas bahan asal stek tercermin pada tingkat energi yang terkandung di dalamnya, terutama kandungan nitrogen yang berperan dalam proses pembelahan dan perpanjangan sel, bahwa kandungan tersebut lebih terdapat pada stek batang tengah $\left(\mathrm{S}_{2}\right)$ dan batang pangkal $\left(\mathrm{S}_{3}\right)$ dari pada stek pucuk $\left(\mathrm{S}_{1}\right)$ yang memiliki kandungan nitrogen lebih rendah. Kemampuan stek membentuk tunas dan akar dipengaruhi oleh adanya karbohidrat, nitrogen dan keseimbangan hormon (auksin) yang tercemin pada nisbah C dan N. Rismunandar (1995) mengatakan bahwa 
pada laju pertumbuhan tinggi tunas pada stek disebabkan adanya ketersediaan kandungan energi yang diperlukan. Bila kandungan karbohidrat rendah maka kandungan protein tinggi, stek akan lebih cepat mendukung pertumbuh tinggi tunas.

Tabel 6. Pengaruh perlakuan media tanam terhadap panjang tunas tanaman nilam

\begin{tabular}{|c|c|c|c|}
\hline Perlakuan & Kode & $\begin{array}{l}\text { Nilai } \\
\text { Rata- } \\
\text { Rata } \\
\text { (cm) }\end{array}$ & $\begin{array}{l}\text { Nota } \\
\text { si }\end{array}$ \\
\hline Tanah & $\mathrm{M}_{0}$ & 15,4 & $\mathrm{a}$ \\
\hline Tanah:Cocopeat (1:1) & $\mathrm{M}_{1}$ & 5,0 & $\mathrm{~b}$ \\
\hline Tanah:Cocopeat (1:2) & $\mathrm{M}_{2}$ & 5,0 & $\mathrm{~b}$ \\
\hline Tanah:Cocopeat (2:1) & $\mathrm{M}_{3}$ & 6,7 & $\mathrm{~b}$ \\
\hline
\end{tabular}

Keterangan: Notasi huruf yang sama pada Tabel menunjukkan tidak beda nyata, notasi huruf yang berbeda menunjukkan beda nyata.

Dari tingkat pertumbuhan tersebut dapat dinyatakan bahwa dari perlakuan media tanah $\left(\mathrm{M}_{0}\right)$ menghasilkan pertumbuhan diameter tunas yang lebih baik daripada perlakuan campuran tanah:cocopeat. Diduga media tanah $\left(\mathrm{M}_{0}\right)$ menyediakan unsur hara nitrogen, dimana unsur hara tersebut sangat penting membantu dalam pertumbuhan tunas. Walaupun memiliki kadar yang terbatas, ketersediaan nitrogen dalam tanah dapat tercukupi untuk membentuk pertumbuhan diameter tunas. Menurut Putri et al (2018) unsur hara nitrogen yang terkandung dalam suatu media berfungsi untuk meningkatkan pertumbuhan vegetatif, mempercepat pembentukan batang yaitu berperan dalam laju pertumbuhan dan perkembangan tunas. Adapun media campuran tanah:cocopeat menunjukkan hasil yang rendah dan masing-masing memiliki hasil yang hampir serupa. Sukarman et al (2012) menyatakan bahwa pemakaian media cocopeat mempunyai kekurangan yaitu memiliki kandungan zat tanin di dalamnya, senyawa tanin yang berasal dari cocopeat merupakan salah satu senyawa penghalang mekanis dalam penyerapan unsur hara.

\section{g. Luas Daun}

Luas daun menjadi parameter utama karena laju fotosintesis pertumbuhan per satuan tanaman dominan ditentukan oleh luas daun. Fungsi utama daun adalah sebagai tempat berlangsungnya proses fotosintesis. Pengamatan daun didasarkan pada fungsinya sebagai penerima cahaya dan tempat terjadinya fotosintesis (Sitompul \& Guritno, 1995).

Tabel 7. Pengaruh perlakuan media tanam terhadap luas daun tanaman nilam

\begin{tabular}{llll}
\hline & & $\begin{array}{l}\text { Nilai } \\
\text { Rata- } \\
\text { Rata }\end{array}$ & \\
Perlakuan & Kode & (cm) & Notasi \\
\hline Tanah & $\mathrm{M}_{0}$ & 11,3 & $\mathrm{a}$ \\
Tanah:Cocopeat (1:1) & $\mathrm{M}_{1}$ & 6,7 & $\mathrm{~b}$ \\
Tanah:Cocopeat (1:2) & $\mathrm{M}_{2}$ & 6,4 & $\mathrm{~b}$ \\
Tanah:Cocopeat (2:1) & $\mathrm{M}_{3}$ & 7,6 & $\mathrm{~b}$ \\
\hline
\end{tabular}

Keterangan: Notasi huruf yang sama pada Tabel menunjukkan tidak beda nyata, notasi huruf yang berbeda menunjukkan beda nyata.

Dari tingkat pertumbuhan tersebut dapat dinyatakan bahwa perlakuan media tanah $\left(\mathrm{M}_{0}\right)$ menghasilkan pertumbuhan luas daun yang lebih baik daripada perlakuan campuran media tanah:cocopeat. Hal ini diduga walau media tanam tanah memiliki kandungan unsur hara yang terbatas ternyata dapat menyediakan unsur hara yang cukup terutama $\mathrm{P}$ (fosfor) dan $\mathrm{N}$ (nitrogen), dalam perkembangan luas daun. unsur $\mathrm{P}$ (fosfor) dalam tanah berperan dalam proses pembelahan sel, fotosintesis dan proses respirasi, sehingga mendorong pertumbuhan tanaman pada bagian daun (Hakim et al, 1986) sedangkan pada unsur $\mathrm{N}$ (nitrogen) merupakan penyusun utama biomassa tanaman yang berperan dalam merangsang pertumbuhan vegetatif dan berpengaruh pada perkembangan luas permukaan daun tanaman Suriatna (1988 cit Daryadi et al, 2017).Adapun media campuran tanah:cocopeat menunjukkan hasil yang rendah dan masing-masing memiliki hasil yang hampir serupa. Keadaan tersebut disebabkan cocopeat yang digunakan memiliki kandungan zat tanin yang tinggi sehingga dapat memperlambat laju pertumbuhan tanaman. Cocopeat juga mengandung klor yang cukup tinggi, bila klor bereaksi dengan air maka akan terbentuk asam klorida (Astuti et al, 2018).

\section{h. Berat Berangkas Kering}

Berat kering pada tanaman adalah salah satu indikator pertumbuhan pada tanaman karena berat kering tanaman merupakan hasil akumulasi asimilat tanaman yang diperoleh dari total pertumbuhan dan perkembangan tanaman selama hidupnya, semakin besar berat kering brangkasan berarti semakin baik pertumbuhan 
dan perkembangan tanaman tersebut (Mursito \& Kawiji, 2002).

Tabel 8. Pengaruh perlakuan media tanam terhadap berat berangkas kering tanaman nilam

\begin{tabular}{|c|c|c|c|}
\hline Perlakuan & Kode & $\begin{array}{l}\text { Nilai } \\
\text { Rata- } \\
\text { Rata } \\
\text { (gram) }\end{array}$ & Notasi \\
\hline Tanah & $\mathrm{M}_{0}$ & 4,6 & $\mathrm{a}$ \\
\hline Tanah:Cocopeat $(1: 1)$ & $\mathrm{M}_{1}$ & 2,1 & $\mathrm{~b}$ \\
\hline Tanah:Cocopeat $(1: 2)$ & $\mathrm{M}_{2}$ & 2,0 & $\mathrm{~b}$ \\
\hline Tanah:Cocopeat (2:1) & $\mathrm{M}_{3}$ & 3,3 & $\mathrm{~b}$ \\
\hline
\end{tabular}

Keterangan: Notasi huruf yang sama pada Tabel menunjukkan tidak beda nyata, notasi huruf yang berbeda menunjukkan beda nyata.

Dari hasil tersebut dapat dinyatakan bahwa perlakuan media tanah $\left(\mathrm{M}_{0}\right)$ menunjukkan berat berangkas kering tertinggi daripada perlakuan campuran media cocopeat. Diduga ketersediaan unsur hara luas yang terkandung pada perlakuan tanah $\left(\mathrm{M}_{0}\right)$ memberikan pembentukan yang baik terhadap pertumbuhan organ bagi tanaman nilam sehingga menghasilkan bobot kering nilam lebih besar. Lingga \& Marsono (2000 cit Qaidah, 2019) mengatakan bahwa media dengan tingkat kesuburan tanah yang seimbang mampu menyediakan unsur hara yang dapat larut di air tanah dalam jumlah yang cukup untuk mendukung pertumbuhan normal tanaman. Adapun media campuran tanah:cocopeat menunjukkan hasil yang rendah dan masingmasing memiliki hasil yang hampir serupa. Sukarman et al (2012) mengatakan bahwa kandungan pada media cocopeat terdapat zat tanin yang merupakan senyawa penghalang mekanisme dalam penyerapan unsur hara, zat tannin yang terkandung dalam media cocopeat tersebut berperan sebagai penghambat aktivitas hormon giberelin dan mengganggu proses transpot unsur hara terutama $\mathrm{N}$ (nitrogen) dan $\mathrm{P}$ (fosfor).

\section{KESIMPULAN}

1. Perlakuan bahan asal stek berpengaruh nyata terhadap parameter pertumbuhan jumlah tunas, jumlah daun, panjang tunas, dan serta presentasi hidup pada tanaman nilam.

2. Perlakuan media tanam berpengaruh nyata terhadap parameter panjang tunas, diameter tunas, luas daun, dan berangkas kering pada tanaman nilam.

3. Interaksi dari perlakuan bahan asal stek dan media cocopeat menunjukkan tidak berpengaruh nyata terhadap semua parameter (persentase hidup stek, jumlah tunas, jumlah daun, panjang tunas, diameter tunas, luas daun dan berat berangkas kering).

\section{DAFTAR PUSTAKA}

Astuti, P., Zulfita, D., Rahmidiyani. 2018. Pengaruh Kombinasi Media Tanam Terhadap Pertumbuhan dan Hasil Jahe Merah. Budidaya Pertanian Universitas Tanjungpura. Vol. 8 (1) : 24-25. Pontianak.

Daryadi., Ardian .2017. Pengaruh Pemberian Kompos Ampas Tahu Dan Pupuk NPK Terhadap Pertumbuhan Bibit Kakao (Theobroma cacao L.). Fakultas Pertanian. Program Studi Agroteknologi. Universitas Riau. Riau.

Dirjenbun. 2017. Statistic Perkebunan Indonesia 2015-2017 Nilam (Tree Crop Estate Statistics of Indonesia 2015-2017 Nilam). Secretariat Direktorat Jendral Perkebunan, Kementerian Pertanian. Jakarta.

Hartman H.T., Kester D.E., \& Davies Jr. F. T. 1990. Plant Propagation, Principles and Practices. Fifth edition. Prentice-Hall Inc. New Jersey.

Krismawati, A. 2005. Nilam dan Potensi Pengembangannya Kalimantan Tengah Jadikan Komoditas Rintisan. PT DKS Sinar tani. Kalimantan Tengah.

Lakitan. 2000. Dasar- Dasar Fisiologi Tumbuhan. PT. Raja Grafindo Persada. Jakarta.

Mangun, H.M.S., Waluyo, H., Purnama, S. A. 2012. Nilam, hasilkan Rendemen Minyak Hingga 5 Kali Lipat Dengan Fermentasi Kapang. Penebar Swadaya. Jakarta.

Mursito, D., Kawiji. 2002. Pengaruh Kerapatan Tanam dan Kedalaman Olah Tanah Terhadap Hasil Umbi Lobak (Raphanus sativus L.). Jurnal Agrosains. Vol. 4 (1) Hal. 1-6.

Putri, F. B., Fakhrurrozi, Y., Rahayu, S. 2018. Pengaruh Perbedaan Jenis Media Tanam Terhadap Pertumbuhan Stek Hoya coronaria Berbunga Kuning Dari Kawasan Hutan Kerangas Air Anyir, Bangka. 
Jurusan Biologi. Universitas Bangka Belitung. Vol. 3 (1) : 3-5. Bangka Belitung. Qaidah, W. 2019. Pengaruh Komposisi Media Tanam Dan Dosis Pupuk Kandang Kambing Terhadap Pertumbuhan Stek Tanaman Murbei (Morus alba L.) Skripsi. Silvikultur, Fakultas Pertanian Program Studi Kehutanan. Universitas Mataram. Mataram.

Rismunandar. 1995. Budidaya Bunga Potong. Penebar Swadaya Pressindo. Jakarta.

Risnawati, B. 2016. Pengaruh Penambahan Serbuk Sabut Kelapa (Cocopeat) pada Media Arang Sekam Terhadap Pertumbuhan Tanaman Sawi Hijau (Brassica juncea L.) Secara Hidroponik. Skripsi. Fakultas Sains dan Teknologi, Universitas Islam Negeri Alauddin. Makasar.

Rusli, M.S. 2010. Sukses Memproduksi Minyak atsiri. PT Agromedia Pustaka. Jakarta.

Sitompul, S. M., dan Guritno B. 1995. Analisis Pertumbuhan Tanaman. Gadjah Mada University Press. Yogyakarta.

Sukarman., Kainde, R., Rombang, J., \& Thomas, A. 2012. Pertumbuhan Bibit Sengon (Paraserianthes Falcataria) pada Berbagai Media Tumbuh. Jurnal Eugenia Vol. 18 (3) Hal. 215-221. Manado.

Sumiati. 1999. Pengaruh Konsentrasi Pupuk Daun cair dan Zat Pengatur Tumbuh Terhadap Pertumbuhan dan hasil Tanaman Mentimun Jepang. Skripsi . UNS Press. Surakarta.

Syakir, M., M.H. Bintoro, D., Amrin Y. D. 1992. Pengaruh Berbagai Zat

Pengatur Tumbuh dan Bahan Setek terhadap Pertumbuhan Setek Cabang

Buah Lada. Pembr Littri. Vol. 19 (3-4) : 5965. Bogor.

Yustisia, D. 2016. Respon Pemberian Berbagai Konsentrasi Air Kelapa Pada Pertumbuhan Stek Nilam (Pogostemon Cablin Bent). Jurnal Agrominansia, Vol. 1 (1) : 4-6 . STIP Muhammadiyah Sinjai. Sulawesi Selatan. 